\title{
NAAR HET LICHTSCHIP
}

\author{
DOOR
}

JHR. L. C. VAN PANHUYS.

Bij mijn aankomst in Suriname in Februari 1892 werd mijn bagage van de loods aan den steiger van den Koninklijken Westindischen maildienst te Paramaribo, waar ik voor mijn in den winter in patria aangeschafte uiteraard niet gedragen tropische uitrusting (kleederen) een niet onaanzienlijk bedrag aan inkomende rechten moest betalen, naar het pension gebracht van mevrouw de weduwe van Vught, waar ik mij zou vestigen, op een soort van met een ezel bespannen ladderwagentje vervoerd door een heel zuiver Nederlandsch sprekenden neger, die mij vertelde, dat hij ,Jamessie" heette, verder dat hij af en toe dienst deed als roeier van de loodsboot, die zich, tegen dat mailschepen verwacht werden, begaf naar het in zee ter hoogte van de monding van de Suriname-rivier geposteerde vuur- of lichtschip. Het kwam tot een uitnoodiging van hem, toen ik hem later op straat te Paramaribo tegenkwam, om het tochtje naar het lichtschip mede te maken, en te eerder gaf ik daaraan gaarne gevolg, omdat de herinnering aan de heerlijke frissche zeereis en het warme stadverblijf te Paramaribo mij zeer naar een uitstapje naar zee deed deed verlangen. James zou aan boord voor mij koken en de visch, die wij hoopten, eigenlijk wel zeker wisten, daar te zullen vangen, voor mij toebereiden; het verblijf aldaar zou, de vermoedelijke komst van het mailschip in aanmerking genomen, twee of drie dagen duren. De uitreis zou plaats hebben met het groote zeilschip Lalla Rookh, aldus genaamd naar den laatst overgeblevenen inboorling van de sedert uitgestorven oorspronkelijke bevolking van het eiland Van Diemensland of Tasmania - kapitein Millichap - dat juist een transport van verscheidene honderden Britschindische immigranten van Britsch-Indië naar Suriname had overgebracht, en weer via de zuidpunt van Afrika de terugreis naar het verre Azië zou aanvaarden. 
Ik kwam met mijn handkoffertje en in stevige, doch eenvoudige, Hollandsche, dus niet-tropische, kleeding en met mijn plaid over den arm, met James aan boord van het, in mijn oogen majestueuse schip en keek mij de oogen uit. De eerste stuurman vond het best, dat ik meeging en ik bezichtigde de eenvoudige, kraakzindelijke, voor emigrantenlogies gebouwde en ingerichte verblijfplaatsen en slaapgelegenheden benedendeks. James scheen over diplomatieke talenten te beschikken. Of hij mij bij zijn superieuren als ,hulproeier" had aangemeld, ben ik niet te weten gekomen, doch hij scheen bij hen een wit voetje te hebben, want zoowel de loods, tot wiens gevolg ik nu behoorde, als de scheepsofficieren waren even vriendelijk.

Het wachten was nog op den kapitein en nu wilde ik mijnerzijds aan den eersten stuurman een kleine beleefdheid bewijzen. Ik haalde daartoe uit mijn koffertje een stoop uitstekende Hollandsche jenever te voorschijn, die ik had medegenomen om bij gelegenheid James of anderen van het scheepsvolk en mijzelf op een ,oorlam” te kunnen tracteeren, wat naar mijn toenmalig inzicht onvermijdelijk bij het zeeleven behoorde. Doch had ik dat maar niet gedaan. De formidabele oorlam, die mijn nieuwe kennis zich zelf met een ietsje te veel begeerigheid klaarblijkelijk met groot genoegen inschonk, was in dit geval juist de druppel, die den emmer deed overloopen; hij had, naar mij achteraf duidelijk werd, reeds te voren aan wal zooveel afscheidsdronken gebruikt, dat hij tot nog toe net éven bekwaam was, om zich te kunnen beheerschen. Maar nu werd het mis. Zijn spraak werd belemmerd, zijn gang onzeker en juist op dat oogenblik kwam een matroos op een zeer correcte wijze, die mij een hoog denkbeeld gaf van de vormen op een Engelsch koopvaardijschip, rapporteeren, dat de kapitein (wij lagen reeds op stroom) het schip naderde. Eerst nu werd mij duidelijk, dat ik verkeerd had gehandeld; mijn vriend de stuurman stotterde zachtjes, dat het streng verboden was sterken drank aan boord te brengen, dat de kapitein de stoop niet mocht zien; hij wikkelde de flesch vlug in eenige kleederen en stopte ze met zijn laatste krachten in mijn handkoffer, die hij zorgvuldig sloot.

De kapitein, klein van stuk, donker, geheel een gentleman, stapte vlug over het dek, werd naar behooren gesalueerd en gaf heel kort maar ferm en op gewonen spreektoon bevel te vertrekken. Op het eerste commando van den zich tot nog toe rechtop gehouden hebbenden eersten stuurman, gaf hij dezen één blik, even uit een van de ooghoeken, en het was of de kapitein, toen hij 
den toestand van zijn officier bemerkte, in eens in lengte toenam en er een wonderbare, beheerschte kracht van hem uitging. Met een vingerbeweging gebood hij hem het commando verder aan hem over te laten, en kort afgebeten gaf hij nu zelf de bevelen, die door het scheepsvolk met ongeloofelijke vlugheid en stiptheid werden gehoorzaamd. Het hijschen en zich ontplooien, het daarna zwellen van de reusachtige zeilen, geleidelijk aan alle drie de masten, de in mijn oogen prachtige harmonie van de bewegingen van de matrozen op de ra's, zoo hoog in de lucht; het ontzagwekkende geheel van een levend schijnend vaartuig van zoo groote afmetingen met een karakter van geweldige rust en schoonheid, overweldigde mij. Het was voor mij, landrot, zulk een verrassend gezicht; ik onderging zóózeer de grootschheid van het geheel, dat ik geruimen tijd als verstijfd stond en van vreugde en ontroering den adem telkens inhield. Het imposante vaartuig - hoeveel schooner, of van welk een andere soort schoonheid, is het groote zeilschip bij een stoomer vergeleken - begon reeds tijdens de manoeuvers van zeilenhijschen te hellen; de masten kraakten licht en een geruisch aan den boeg vertolkte, dat een niet onaanzienlijke snelheid werd bereikt. Was het mijn roerlooze stand en de blijdschap op mijn gezicht, die den kapitein opviel? Hij informeerde met enkele woorden binnensmonds bij den tweeden stuurman naar den eenigszins ongewonen hulproeier, en met een haast onmerkbaren zweem van een glimlach en vermoedelijk met inzicht in mijn groote sportieve blijdschap vroeg hij den hulproeier... ten eten. De volgende kwartieren waren als in een droom. In korten tijd zeilden wij de Suriname-rivier uit en was het oogenblik van afscheid gekomen; ik dankte en groette den kapitein en de andere officieren; onze loodsboot stak van het groote zeilschip af, en daar vloog de Lalla Rookh thans in een voortdurend sterker wordenden wind steeds verder naar den horizon, terwijl ik voor het eerst beproefde hoe het gaat om een grooten roeiriem in golfslag te hanteeren. Het zou, door toevallige omstandigheden, eerst 1932, dus veertig jaar later, worden, eer ik, tezamen met mijn oudsten zoon, het diploma als roeier als lid van de Gorkumsche Roei- en Zeilvereeniging zou verwerven.

Aan boord van het lichtschip bleek een, naar 't scheen, niet te overwinnen moeilijkheid. Het lichtschip danste op de golven, en spoedig begreep ik, dat onder zulke omstandigheden - er woei een ferme bries - zeeziekte onvermijdelijk zou zijn, het in ieder geval moeilijk zou worden den genuttigden maaltijd binnen te houden. Ik had (en bezit nog) een eenvoudige, lichte maar van 
sterk touw geknoopte, bij de firma Perry te 's-Gravenhage aan geschafte, hangmat. Door de beide uiteinden bij elkaar aan een balk boven mij vast te sjorren en door, ook bij volgende maaltijden, met mijn bord met eten in de hand in de hangmat te gaan zitten, maakte ik de bewegingen (het slingeren en rollen) van het schip, men denke aan den ring van Cardanus, slechts in geringe mate mede en bleef alles ,,veilig”.

Lectuur had ik meegenomen, maar ik verveelde mij niet. Het waren feestdagen van kleur en licht, van een panorama van zon en wolken. Tegen den avond gingen James en ik op onzen rug liggen boven op het houten dak, dat het scheepsdek tegen de zonnestralen beveiligde en waarboven het lichttoestel zich verhief; daar hielden wij filosophische gesprekken. Ik leerde seinen opzoeken in het seinboek en ... ik sloot er vriendschap met de zee. Ik meen te hebben ondervonden, dat een dergelijk, door de natuur geschonken genot, als mij door het verblijf op het lichtschip te beurt viel, onuitwischbaar is. Want in 1942 las ik toevallig een oproep in het Nederlandsche Studieblad om een heel kort opstel in te zenden. Ik koos uit de opgegeven onderwerpen den eindeloozen oceaan, mijn geweldige vriendin „De Zee”. Het opstelletje vloog mij zóó uit de pen en ... het werd bekroond. Dat zou ik dan mede alsnog aan ,Jamessie" hebben te danken.

Op een avond kregen wij een vuurpeil-sein. Het mailschip was in aantocht. Ik bedankte den goedhartigen, vriendelijk lachenden, zeer donker gekleurden kapitein hartelijk en gaf hem de hand en te spoedig kwam nu aan mijn avontuur een einde. Want wel moesten wij bij een bulderenden wind, die alle „A hoy's" dempte en vervliegen deed, en onder een hevig kabaal van de bruischende golven in de loodsboot, in een onstuimige en woeste, doch prachtig lichtende zee, en uit die boot - een schitterende, levenwekkende en overgetelijke sport - met moeite langs touwen in het donker tegen den hoogen mailstoomer opklimmen, waar ik onder de passagiers een van een verlof in patria terugkeerenden kennis, den heer Schöne, gezagvoerder van de plantage Nieuw Clarenbeek, eigenaar Mr. Muller van Voorst, aantrof, maar met den opkomenden vloed zette ons vaartuig, onder leiding van den bekwamen kapitein A. Duif, met snelheid koers naar Paramaribo, waar de hulproeier na enkele uren verheugd en door zijn uitstapje opgelucht weer aan wal stapte.

18 Januari 1943.

Naschrift. Indien men herinneringen van zoo lang geleden 
ophaalt, is het nagaan, het onderzoeken of men feiten juist heeft weergegeven, eigenlijk een plicht. De gelegenheid tot dat onderzoek deed zich onverwacht voor. Ik stapte naar het Vredespaleis te 's-Gravenhage, waar op de bovenverdieping de Bibliotheek van het Departement van Koloniën tijdelijk is ondergebracht en daar gaf de ambtenaresse, die de bibliotheek tijdelijk beheert, mij welwillend inzage van het Koloniaal Verslag van Suriname van 1893.

Daarin vind ik in het jaarverslag van den Agent-generaal voor de immigratie over het jaar 1892, dat op 18 November 1892 het schip ,British Peer" met een transport immigranten uit BritschIndië, kapitein Millichap, ter hoogte van het fort Nieuw Amsterdam het anker moest laten vallen, omdat het wegens den grooten diepgang niet kon opvaren tot de reede van Paramaribo. Heb ik mij dus in den naam van het schip vergist, dien van den kapitein komt uit, en ook blijkt, dat het vaartuig, dat ongeladen was, van groote afmetingen moet zijn geweest, immers van meer tonnage en diepgang dan de stoomschepen van den Koninklijken Westindischen maildienst, die er op gebouwd waren om over de zoogenaamde bank, ter hoogte van de plantage Jagtlust heen de reede van de hoofdstad te kunnen bereiken.

In het Verslag staat, dat geen enkele klacht door de immigranten werd ingebracht en dat zij verklaarden zeer goed behandeld te zijn gedurende de reis; dat de levensmiddelen en het drinkwater bevonden werden van zeer goede hoedanigheid te zijn; dat het tusschendek behoorlijk werd geventileerd met koelzeilen en door „Blakcman's Patent Ventilator", die door stoom in werking werd gebracht; voorts, dat op de orde en de zindelijkheid, zoowel bovenals tusschendeks niets viel aan te merken. Het doet mij genoegen in een ambtelijk rapport te vinden, dat de flinke kapitein, de overige scheepsofficieren en de bemanning, menschen zijn geweest, die de hun opgedragen taak met nauwlettendheid en ijver hebben vervuld.

Ik wil nog opmerken, dat ik op mijn terugreis van het lichtschip onvoorzichtig geweest ben, doordat ik, bij mijn kennis in de hut mijn handen van teer en olie, bij de beklimming van het schip opgedaan, heb gereinigd. Daardoor kon men denken, dat er een nieuwe eerste-klas passagier aan boord was gekomen. Men waarschuwde mij tenminste, het avontuur niet te herhalen, daar de plichtgetrouwe kapitein er over zou hebben gedacht van mij, voor de passage, van het lichtschip naar de hoofdstad, een vervoerprijs te vorderen, tot een bedrag, waarvan mij, nog onbezoldigd jongmensch, de haren ten berge zouden zijn gerezen. Ik had dus beter mijn incognito dienen te bewaren. 